\title{
Artikel
}

\section{Over het verzet tegen de rekening en verantwoording en de uitdelingslijst van de vereffenaar}

Prof. dr. S. Perrick*

\section{Inleiding}

Recentelijk heeft de Hoge Raad driemaal een oordeel gegeven over in het bijzonder procesrechtelijke aspecten van het verzet tegen een door een vereffenaar gedane rekening en verantwoording of opgemaakte uitdelingslijst. Voor een goed begrip van de door de Hoge Raad gegeven beschikkingen, ook in onderling verband beschouwd, is het van belang een aantal onderscheidingen te maken. Daarna kunnen de relevante rechtsvragen op een eenvoudige wijze worden geïnventariseerd en beantwoord. Daarbij spelen in het bijzonder twee artikelen van het Burgerlijk Wetboek (BW), die beide deel uitmaken van afdeling 4.6.3 BW met het opschrift 'Vereffening van de nalatenschap', een rol. Het eerste is artikel 4:218 BW en het tweede is artikel 4:221 BW.

Artikel 4:218 BW geeft regels voor het geval een vereffenaar verplicht is een rekening en verantwoording benevens een uitdelingslijst neer te leggen. Artikel 4:221 $\mathrm{BW}$ bepaalt wanneer een vereffenaar niet verplicht is een rekening en verantwoording en een uitdelingslijst neer te leggen. Voor dat geval geeft de wet een bijzondere regeling voor de wijze waarop de rekening en verantwoording geschiedt. Het verdient de voorkeur dat ik eerst aandacht besteed aan artikel 4:218 BW. Ook al omdat artikel 4:218 BW op grond van artikel 4:221 BW toch van toepassing kan zijn in gevallen dat dit in beginsel niet het geval is.

* Prof dr. S. Perrick is advocaat te Amsterdam.
Maar alvorens deze wetsbepalingen in paragraaf 3 onderscheidenlijk paragraaf 4 in ogenschouw te nemen, is het nodig dat ik in paragraaf 2 eerst enkele inleidende opmerkingen maak over de verplichting van de vereffenaar om een rekening en verantwoording te doen en een uitdelingslijst op te maken.

In een van de zaken waarover de Hoge Raad oordeelde, speelde de vraag per welk tijdstip hetgeen een erfgenaam/legitimaris als erfgenaam verkrijgt, dient te worden gewaardeerd. Die kwestie behandel ik bij wijze van intermezzo in paragraaf 5.

\section{Verplichting tot het doen van een rekening en verantwoording en het opmaken van een uitdelingslijst}

Afdeling 4.6.3 BW bepaalt niet met zoveel woorden dat de vereffenaar verplicht is tot het afleggen van rekening en verantwoording en het opmaken van een uitdelingslijst. ${ }^{1}$ Uiteraard veronderstelt een verplichting van een vereffenaar om een rekening en verantwoording en een

1. Art. 4:151 BW verplicht de executeur wiens bevoegdheid tot beheer van de nalatenschap is geëindigd rekening en verantwoording af te leggen aan degene die na hem tot het beheer bevoegd is, op de wijze als voor bewindvoerders is bepaald. Zie ten aanzien van de bewindvoerder art. 4:161 lid 1 BW. Art. 4:161 lid 4 BW verklaart het bepaalde aangaande de voogdijrekening van overeenkomstige toepassing. Zie daarover ook par. 4. 
uitdelingslijst neer te leggen, een verplichting om deze eerst op te stellen. Wij zullen hierna in paragraaf 4 echter constateren dat de vereffenaar onder bepaalde omstandigheden niet verplicht is een rekening en verantwoording benevens een uitdelingslijst neer te leggen. In die gevallen is de vereffenaar uitsluitend verplicht een rekening en verantwoording op te stellen. In de rekening en verantwoording legt de vereffenaar rekening en verantwoording af van de wijze waarop hij zijn wettelijke taak heeft vervuld. Daartoe behoort volgens artikel 4:215 lid $1 \mathrm{BW}$ onder meer dat hij de goederen van de nalatenschap te gelde maakt, voor zover dat voor de voldoening van de schulden nodig is. In de rekening en verantwoording zal hij zich ook dienen te verantwoorden voor de wijze waarop hij zijn taak om schulden van de nalatenschap te voldoen heeft vervuld, onder vermelding van de namen van de schuldeisers van de nalatenschap en de bedragen die hij van hun vorderingen heeft voldaan.

\section{Er bestaat een verplichting tot neerlegging van een rekening en verantwoording en een uitdelingslijst}

\subsection{Inleiding}

Het uitgangspunt van artikel $4: 218 \mathrm{BW}$ is dat de vereffenaar verplicht is een rekening en verantwoording benevens een uitdelingslijst ten kantore van de boedelnotaris of, indien deze ontbreekt, ter griffie van de rechtbank ter kennisneming van eenieder neer te leggen. Zoals ik in paragraaf 2 reeds vermeldde, veronderstelt een verplichting om een rekening en verantwoording benevens een uitdelingslijst neer te leggen, een verplichting om deze op te stellen. Bij het opmaken van de uitdelingslijst vinden volgens artikel 4:218 lid 5 BW de dienaangaande in de Faillissementswet $\left(\mathrm{Fw}_{\mathrm{w}}\right)$ voorkomende voorschriften zoveel mogelijk overeenkomstige toepassing. ${ }^{2}$ Het gaat daarbij om de voorschriften van artikel 180 e.v. Fw. Volgens artikel 180 lid 1 Fw houdt de lijst in een staat der ontvangsten en uitgaven (daaronder begrepen het salaris van de curator), de namen der schuldeisers, het geverifieerde bedrag van ieders vordering, benevens de daarop te ontvangen uitkering.

De wet voorziet in afdeling 4.6.3 BW niet in de verificatie van de vorderingen van de schuldeisers van de nalatenschap, ook niet door de desbetreffende bepalingen van de Faillissementswet van overeenkomstige toepassing te verklaren. Voor het 'geverifieerde bedrag' dient in geval van vereffening te worden gelezen het 'bedrag'. Bij het opnemen van het bedrag van een vordering van een schuldeiser in de uitdelingslijst dient de vereffenaar te handelen overeenkomstig een uitspraak van de

2. Zie voor de betekenis van 'zoveel mogelijk' par. 3.2 rechter op de voet van artikel 4:223 lid 2 eerste zin BW omtrent het vorderingsrecht van een schuldeiser, of de voorrang die aan zijn vordering toekomt. Een schuldeiser dient zich deze mogelijkheid goed te realiseren op het tijdstip dat de vereffenaar overeenkomstig artikel 4:214 lid 4 BW aan de schuldeiser kennis geeft van het feit dat hij zich met een ingediende vordering of een ingeroepen voorrang niet kan verenigen. ${ }^{3}$

In bepaalde gevallen, waaraan ik in paragraaf 4 aandacht zal besteden, bestaat geen verplichting om een rekening en verantwoording benevens een uitdelingslijst neer te leggen. Het is daarom van groot belang, zoals ook blijkt uit recente uitspraken van de Hoge Raad, dat de lezer zich realiseert dat artikel 4:218 BW in beginsel slechts van toepassing is ingeval er een verplichting tot neerlegging bestaat.

Volgens artikel 4:218 lid $1 \mathrm{BW}$ is een vereffenaar verplicht binnen zes maanden nadat de voor het indienen van vorderingen gestelde tijd is verstreken een rekening en verantwoording benevens een uitdelingslijst neer te leggen. De kantonrechter kan deze termijn verlengen. ${ }^{4}$ Verlenging kan noodzakelijk zijn indien een schuldeiser heeft verzocht zijn vorderingsrecht, of de voorrang die aan zijn vordering toekomt, bij vonnis te doen vaststellen op de voet van artikel 4:223 lid 2 eerste zin BW en er nog geen rechterlijke uitspraak met kracht van gewijsde is. ${ }^{5}$ Artikel $4: 218$ lid 3 BW bepaalt dat iedere belanghebbende binnen een maand na de openlijke bekendmaking van de neerlegging op de voet van artikel 4:218 lid $3 \mathrm{BW}$ tegen de rekening en verantwoording of tegen de uitdelingslijst in verzet kan komen bij de kantonrechter of, indien een rechter-commissaris is benoemd, bij de rechtbank.

\subsection{Artikel $187 \mathrm{Fw}$ is van overeenkomstige toepassing in geval van beschikking op verzet}

Volgens artikel 4:218 lid $5 \mathrm{BW}$ vinden niet alleen bij de berekening van ieders vordering, maar ook bij het opmaken van de uitdelingslijst en het verzet daartegen de dienaangaande in de Faillisementswet voorkomende voorschriften zoveel mogelijk overeenkomstige toepassing. De wet hanteert de term 'zoveel mogelijk' omdat zij beoogt rekening te houden met het verschil in karakter van de vereffening van een nalatenschap, die regelmatig niet insolvent is, en die van de nagenoeg steeds deficitaire boedel van een schuldenaar die failliet is verklaard. ${ }^{6}$ Voor de bepalingen van de Faillisementswet die volgens artikel 4:218 lid 5 BW zoveel mogelijk overeen-

3. Rb. Noord-Nederland (ktr.) 7 juni 2016, ECLI:NL:RBNNE:2016:2680 gaf in het kader van een procedure op het verzet tegen een uitdelingslijst aan de vereffenaar op de voet van art. 4:210 BW een aanwijzing, in die zin dat hij de schuldeisers een redelijke termijn biedt om op de voet van art. 4:223 lid 2 BW een dagvaardingsprocedure aanhangig te maken.

4. Volgens art. $676 \mathrm{a}$ onder $u \mathrm{Rv}$ staat tegen een beschikking van de kantonrechter tot verlenging van de termijn geen andere voorziening open dan cassatie in het belang der wet. Zie over art. 676a Rv ook par. 3.2 slot en noot 13 .

5. Tegen een vonnis van de rechtbank is hoger beroep mogelijk. Zie over art. 4:223 lid 2 eerste zin BW Asser/Perrick 4 2017/645.

6. Zie Parl. Gesch. BW Boek 4 2002, p. 1014. 
komstige toepassing vinden op het verzet tegen de uitdelingslijst verwijs ik naar artikel 185 e.v. Fw. Volgens artikel 187 Fw kan van de beschikking op het verzet tegen de uitdelingslijst beroep in cassatie worden ingesteld door de curator en iedere schuldeiser. In Asser heb ik het volgende standpunt ingenomen:

'Ik zou willen aannemen dat deze bepaling ook van toepassing is op de beschikking die de rechtbank heeft genomen op een verzet van de vereffenaar of een schuldeiser.' ${ }^{7}$

$\mathrm{Er}$ is in dit geval geen goede reden om artikel $187 \mathrm{FW}_{\mathrm{W}}$ niet toe te passen. Indien er een verplichting tot neerlegging van de rekening en verantwoording en de uitdelingslijst bestaat, zal er doorgaans sprake zijn van een 'deficitaire' nalatenschap. Indien het gaat om een nalatenschap waarvan de schulden ten volle kunnen worden voldaan, is de vereffenaar in beginsel niet verplicht een rekening en verantwoording en een uitdelingslijst neer te leggen. Zie daarover paragraaf 4.

Deze van overeenkomstige toepassing van artikel 187 Fw betekent dat van de beschikking van de kantonrechter of, indien een rechter-commissaris is benoemd, de rechtbank binnen acht dagen nadat zij is gedaan, beroep in cassatie kan worden ingesteld door de vereffenaar en door iedere schuldeiser. Volgens artikel 4:218 lid 3 BW kan iedere belanghebbende tegen de rekening en verantwoording of tegen de uitdelingslijst bij de kantonrechter of, indien een rechter-commissaris is benoemd, bij de rechtbank in verzet komen.

Onder belanghebbende zijn niet alleen de vereffenaar en een schuldeiser begrepen. Daaronder valt zeker ook een erfgenaam. Deze kan bezwaar hebben tegen de rekening en verantwoording en ook tegen de uitdelingslijst. Wat betreft de uitdelingslijst bijvoorbeeld op de grond dat daarop een schuldeiser is opgenomen voor een vordering die door de erfgenaam, gedeeltelijk, wordt betwist. Uit de van overeenkomstige toepassing van artikel 187 Fw volgt, strikt genomen, niet dat de erfgenaam beroep in cassatie kan instellen.

Dat wordt veroorzaakt door het feit dat artikel 187 lid 1 Fw (uitsluitend) noemt 'de curator'; lees bij overeenkomstige toepassing: de vereffenaar, en 'iedere schuldeiser'. De failliet wordt niet genoemd. Zou de failliet wel worden genoemd, dan zou daarvoor bij overeenkomstige toepassing van artikel 187 lid $1 \mathrm{FW}_{\mathrm{W}}$ op de vereffening mogen worden gelezen: de erfgenaam. ${ }^{8}$ Ik acht het verantwoord aan te nemen dat ook een erfgenaam die op de voet van artikel 4:218 lid $3 \mathrm{BW}$ tegen de rekening en verantwoording en/of de uitdelingslijst in verzet is gekomen, tegen de daarop gegeven beschikking van de kantonrechter of de rechtbank, binnen acht dagen nadat zij is gegeven, beroep in cassatie kan instellen. Hier is kennelijk sprake van een, overigens begrijpelijke, omissie van de wetgever. ${ }^{9}$

Ook de Hoge Raad oordeelt in overeenstemming met de door hem geconstateerde bedoeling van de wetgever dat artikel 187 lid $1 \mathrm{FW}_{\mathrm{W}}$ op de procedure bij de vereffening van een nalatenschap van toepassing is. ${ }^{10}$

Op grond van artikel 358 in samenhang met artikel 261 van het Wetboek van Burgerlijke Rechtsvordering ( $\mathrm{Rv})$ staat tegen een beschikking op het verzet hoger beroep open '[v]oor zover uit de wet niet anders voortvloeit'. Volgens de Hoge Raad laat deze formulering een afwijking in algemene bewoordingen, zoals in artikel 4:218 lid $5 \mathrm{BW}$ in verbinding met artikel 187 lid $1 \mathrm{Fw}$, toe.

Een beschikking van de kantonrechter of de rechtbank op een verzet wordt terecht niet genoemd in artikel 676a Rv. Tegen de in deze bepaling opgesomde beschikkingen is geen andere voorziening toegelaten, behoudens beroep in cassatie in het belang der wet.

\subsection{Belang dat uitsluitend beroep in cassatie kan worden ingesteld}

Het is uiteraard van belang dat een vereffenaar of een belanghebbende zich realiseert dat tegen een beschikking van de kantonrechter of de rechtbank op een verzet tegen de rekening en verantwoording of tegen de uitdelingslijst geen hoger beroep, maar uitsluitend beroep in cassatie openstaat en dat hij dat beroep binnen acht dagen moet instellen.

Het feit dat alleen beroep in cassatie kan worden ingesteld, betekent dat in beginsel artikel 80 lid 1 van de Wet op de rechterlijke organisatie (Wet RO) van toepassing is. Volgens deze bepaling kan een partij tegen een beschikking van een kantonrechter in een burgerlijke zaak waartegen geen hoger beroep kan of kon worden ingesteld, slechts beroep in cassatie instellen wegens:

'a. het niet inhouden van de gronden waarop het vonnis of de beschikking berust;

b. het niet in het openbaar gedaan zijn van het vonnis of, voorzover rechtens vereist, de beschikking;

c. onbevoegdheid; of

d. overschrijding van rechtsmacht'.

Door de Hoge Raad is een vijfde grond aanvaard, te weten de schending van een zo fundamenteel rechtsbeginsel dat van een eerlijke en onpartijdige behandeling van de zaak niet kan worden gesproken, zoals het geval is bij het niet in acht nemen van het contradictoire beginsel, waartoe hoor en wederhoor behoort, en van het recht op gelijke behandeling (equality of arms). ${ }^{11}$

9. Men mag dus ook niet aannemen dat voor de erfgenaam op grond van art. 358 in samenhang met art. 261 Rv tegen een beschikking op het verzet hoger beroep openstaat.

10. HR 21 december 2018, ECLI:NL:HR:2018:2393, NJ 2019/39. De Hoge Raad verwerpt de in cassatie opgeworpen klacht dat art. 187 lid 1 Fw niet van toepassing is op beschikkingen van de kantonrechter, nu in deze bepaling alleen wordt gesproken van beschikkingen van rechtbanken. Deze klacht faalt volgens de Hoge Raad reeds omdat de kantonrechter onderdeel uitmaakt van de rechtbank.

11. Zie HR 16 maart 2007, ECLI:NL:HR:2007:AZ1490, NJ 2007/637 m.nt. H.J. Snijders. 
Dit betekent dat in cassatie slechts een beperkte toetsing mogelijk is. Ervan uitgaande dat de gronden b, c en d van artikel 80 lid 1 Wet RO niet aan de orde zijn, en ook geen sprake is van de schending van bedoeld fundamenteel rechtsbeginsel, kunnen in cassatie slechts motiveringsklachten worden behandeld en derhalve geen rechtsklachten. Deze motiveringsklachten vallen onder de cassatiegrond genoemd in artikel 80 lid 1 onder a Wet RO. ${ }^{12}$

Ik merk nog op dat als de beschikking op verzet volgens artikel 4:218 lid 3 BW door een rechtbank wordt gegeven, omdat er een rechter-commissaris is benoemd, de door artikel 80 lid 1 Wet RO aangebrachte beperking in de gronden voor cassatie niet van toepassing is. Een beroep in cassatie tegen een beschikking van de rechtbank kan derhalve ook op rechtsgronden worden gebaseerd.

Uit het vorenstaande volgt dat het aantal gronden waarop de Hoge Raad een beroep in cassatie tegen een beschikking van een kantonrechter op een verzet tegen een uitdelingslijst kan honoreren, beperkt is. Maakt een schuldeiser niet tijdig gebruik van de aan hem door artikel 4:223 lid 2 eerste zin BW gegeven mogelijkheid, dan is de kans groot dat de facto tegen een onjuiste beslissing van de kantonrechter geen hogere voorziening openstaat.

\section{Er bestaat geen verplichting tot neerlegging}

In bepaalde gevallen, waarop artikel 4:221 BW het oog heeft, is de vereffenaar niet verplicht een rekening en verantwoording en een uitdelingslijst neer te leggen. Als dat geval zich voordoet, is artikel 4:218 lid 3 BW niet van toepassing en kan een belanghebbende dus niet op de daar aangegeven wijze in verzet komen tegen de rekening en verantwoording of de uitdelingslijst.

Artikel 4:221 BW maakt een onderscheid tussen twee gevallen.

Ten eerste het geval dat de nalatenschap onder het voorrecht van boedelbeschrijving is aanvaard en de erfgenamen vereffenaars zijn. Voor dat geval bepaalt artikel 4:221 lid $1 \mathrm{BW}$ dat de in artikel 4:214 lid 1 en 5 en 4:218 BW omschreven verplichtingen slechts op de erfgenamen/vereffenaars rusten indien de kantonrechter dat bepaalt. Bepaalt de kantonrechter niet anders, dan behoeven de erfgenamen/vereffenaars de schuldeisers van de nalatenschap niet openlijk op te roepen om hun vorderingen bij de boedelnotaris of, indien deze ontbreekt, bij henzelf in te dienen, behoeft geen lijst met door de erfgenamen/vereffenaars erkende en betwiste vorderingen en aanspraken op voorrang te worden neergelegd, en behoeven de erfgenamen/vereffenaars niet op grond van en op de voet van artikel 4:218 lid $1 \mathrm{BW}$ een

12. Zie verder de instructieve conclusie van A-G Rank-Berenschot, ECLI:NL:PHR:2020:322, onder 2.18, voorafgaande aan HR 17 juli 2020, ECLI:NL:HR:2020:1306. rekening en verantwoording benevens een uitdelingslijst neer te leggen. Ik wijs erop dat de erfgenamen/vereffenaars in dit geval geen uitdelingslijst behoeven op te stellen. Wel dienen ook deze vereffenaars op grond van artikel 4:211 lid 3 eerste zin BW met bekwame spoed een onderhandse of notariële boedelbeschrijving op te maken of te doen opmaken, waarin de schulden van de nalatenschap in de vorm van een voorlopige staat zijn opgenomen. En deze boedelbeschrijving moeten de vereffenaars volgens artikel 4:211 lid 3 tweede zin BW op de daar aangegeven wijze ter inzage leggen. ${ }^{13}$

De kantonrechter kan bepalen dat artikel 4:214 lid 1 en 5 en 4:218 BW wel van toepassing zijn. Voor dat geval verwijs ik naar mijn betoog in paragraaf 3 .

Fungeert er een door de rechter benoemde vereffenaar, het tweede geval, dan is artikel 4:221 lid 2 BW van belang. Een door de rechter benoemde vereffenaar kan in functie zijn zowel in het geval de nalatenschap onder het voorrecht van boedelbeschrijving is aanvaard als in het geval dat dit niet zo is. In beide gevallen kan zich een omstandigheid voordoen waarop artikel 4:221 lid 2 BW het oog heeft. In het geval van aanvaarding onder het voorrecht van boedelbeschrijving is daarvan sprake indien er een door de rechter op de voet van artikel 4:203 BW persoon is benoemd die als vereffenaar in de plaats is getreden van de erfgenamen. Ook in dat geval is lid 2, en dus niet lid 1, van artikel 4:221 BW van toepassing.

Volgens artikel 4:221 lid 2 BW behoeft de vereffenaar geen rekening en verantwoording en geen uitdelingslijst neer te leggen wanneer alle hem voor de afloop van de in artikel 4:218 lid $1 \mathrm{BW}$ bedoelde termijn, dat wil zeggen: binnen zes maanden nadat de voor het indienen van vorderingen gestelde termijn is verstreken, bekend geworden schulden ten volle worden voldaan, of wanneer de kantonrechter de vereffenaar van deze verplichting vrijstelt; deze vrijstelling wordt niet verleend wanneer een schuldeiser daartegen bezwaar maakt. Het zal hier gaan om een schuldeiser wiens vordering niet ten volle is voldaan.

Voor beide typen gevallen, dus zowel die waarop artikel 4:221 lid $1 \mathrm{BW}$ als die waarop artikel 4:221 lid 2 BW ziet, geldt artikel 4:221 lid 3 BW. Dat betekent dat de rekening en verantwoording, die niet behoeft te worden neergelegd, dient te geschieden aan hen die een recht op het overschot hebben, en wel op de wijze als voor bewindvoerders is bepaald. Degenen die recht op het overschot hebben, zijn allereerst de erfgenamen, of in geval van een wettelijke verdeling de langstlevende echtgenoot, of de Staat, maar daaronder vallen ook zij aan wie het vruchtgebruik van de nalatenschap of van een aandeel daarin is vermaakt. ${ }^{14}$

13. Tenzij de kantonrechter de erfgenamen/vereffenaars van deze verplichting ontheft, hetgeen art. 4:211 lid 4 BW mogelijk maakt. Tegen een beschikking tot ontheffing van de kantonrechter staat op grond van art. 676a aanhef en onder s Rv geen andere voorziening dan cassatie in het belang der wet open.

14. Zie Asser/Perrick 4 2017/630, onder verwijzing naar Parl. Gesch. BW Boek 4 2002, p. 1024 en art. 4:226 BW, waarover Asser/Perrick 4 $2017 / 648$. 
Artikel 4:221 lid 3 BW verwijst voor de wijze waarop de rekening en verantwoording geschiedt naar de aan bewindvoerders gestelde voorschriften. Deze treffen wij aan in artikel 4:161 BW. De verwijzing in artikel 4:221 lid $3 \mathrm{BW}$ heeft tot gevolg dat op de door de vereffenaar af te leggen rekening en verantwoording artikel 4:161 lid $4 \mathrm{BW}$ van toepassing is. En dat betekent dat het bepaalde in paragraaf 10 en 11 van afdeling 1.14.6 BW aangaande de voogdijrekening van overeenkomstige toepassing is. Dientengevolge worden geschillen die bij het afleggen van de rekening en verantwoording rijzen overeenkomstig artikel 1:374 lid $2 \mathrm{BW}$, dat deel uitmaakt van paragraaf 11 van afdeling 1.14.6 BW, beslist door de kantonrechter. Tegen een beschikking van de kantonrechter staat volgens artikel 358 en $261 \mathrm{Rv}$ hoger beroep open. Dit hoger beroep moet volgens artikel 358 lid $2 \mathrm{Rv}$ worden ingesteld binnen drie maanden.

Zie voor een geval dat de vereffenaar een eindbeschikking van de kantonrechter (ten onrechte) had aangemerkt als een beschikking op verzet als bedoeld in artikel 4:218 lid 3 BW, waartegen slechts cassatieberoep openstaat op de voet van artikel 4:218 lid $5 \mathrm{BW}$ in verbinding met artikel 187 lid 1 Fw: HR 17 juli 2020, ECLI:NL:HR:2020:1311, NJ 2020/308. De Hoge Raad verklaart de vereffenaarster niet-ontvankelijk in haar beroep. De Hoge Raad wijst verzoekster erop dat nu cassatieberoep tijdig is ingesteld, maar tegen de eindbeschikking van de kantonrechter geen cassatieberoep openstaat, de termijn van hoger beroep tegen de eindbeschikking opnieuw aanvangt, te rekenen van de dag van deze uitspraak in cassatie. Dat bepaalt artikel $340 \mathrm{Rv}$, waarnaar de Hoge Raad verwijst. Hij laat het niet bij dit advies en neemt vervolgens in ogenschouw de mogelijkheid dat het hof in een eventuele appelprocedure tot het oordeel komt dat het verzoek van verweerders in cassatie wel moet worden aangemerkt als een verzet in de zin van artikel 4:218 lid $3 \mathrm{BW}$. Het hof zal de beschikkingen van de kantonrechter in zoverre moeten vernietigen en zal alsnog op het verzet van verweerders moeten beslissen, terwijl in dat geval tegen die beschikking van het hof cassatieberoep openstaat. De Hoge Raad houdt rekening met de mogelijkheid dat het hof het oordeel van de Hoge Raad eventueel niet overneemt en wil hier kennelijk de moeilijkheid vermijden dat het hof er in het veronderstelde geval mee volstaat de vereffenaar nietontvankelijk te verklaren. Dan zou de vereffenaar zich als het ware tussen wal en schip bevinden. De Hoge Raad heeft het beroep in cassatie niet inhoudelijk beoordeeld en het hof zou dat in het veronderstelde geval evenmin doen. ${ }^{15}$ Ik neem aan dat de Hoge Raad de beschikking van het hof inhoudelijk zal beoordelen en deze zal aanmerken als een beschikking op de voet van artikel 1:374 lid 2 BW.

Ook indien alle bekend geworden schulden ten volle (kunnen) worden voldaan, kan een partij die ingevolge artikel 4:221 lid 3 BW gerechtigd is op het overschot,

15. A-G Vlas had in 2.9 van zijn conclusie, ECLI:NL:PHR:2020:120, op deze mogelijke 'kafkaëske situatie' gewezen. een erfgenaam, er belang bij hebben bezwaar te maken tegen een uitdelingslijst. Bijvoorbeeld omdat de vereffenaar een door de erfgenaam betwiste vordering in de uitdelingslijst heeft opgenomen, met als gevolg dat aan hem minder 'overschot' toekomt. Aan deze erfgenaam komt niet de bevoegdheid toe te bewerkstelligen dat hij tegen een neergelegde uitdelingslijst bezwaar kan maken. In paragraaf 2 heb ik erop gewezen dat afdeling 4.6.3 BW niet met zoveel woorden op de vereffenaar de verplichting legt om een rekening en verantwoording en een uitdelingslijst op te stellen, maar dat over een dergelijke verplichting uiteraard geen enkele twijfel bestaat in het geval dat de vereffenaar verplicht is een rekening en verantwoording en een uitdelingslijst neer te leggen. Het lijkt erop dat het de bedoeling van de wetgever is dat in het geval een door de rechter benoemde vereffenaar niet een rekening en verantwoording en een uitdelingslijst behoeft neer te leggen, er geen verplichting bestaat tot het opmaken van een uitdelingslijst. De wet geeft geen voorschriften omtrent de inrichting van de rekening en verantwoording. Een rekening en verantwoording zonder opgave van de ontvangsten en de uitgaven is geen rekening en verantwoording. ${ }^{16}$ De rekening en verantwoording dient dus betrekking te hebben op de schulden die de vereffenaar heeft voldaan. Een geschil daarover is ook een geschil als bedoeld in artikel 1:374 lid 2 BW, waarover de kantonrechter besliste. In de door de Hoge Raad berechte zaak ging het om verzet tegen de 'rekening en verantwoording/slotuitdelingslijst'. Bij het opmaken van de 'slotuitdelingslijst' is artikel 4:218 lid $5 \mathrm{BW}$, en dientengevolge het bepaalde in de Faillissementswet, niet van (overeenkomstige) toepassing. Het praktische belang dat de erfgenaam zou kunnen hebben bij de mogelijkheid dat de vereffenaar ook in dit geval verplicht is een afzonderlijke uitdelingslijst op te stellen waartegen hij bezwaar kan maken, is dat de vereffenaar in dat geval niet zou mogen uitkeren zolang niet in hoogste instantie op het bezwaar tegen de uitdelingslijst is beslist.

\section{Intermezzo}

De Hoge Raad verwierp in HR 17 juli 2020, ECL:NL:HR:2020:1306, in overeenstemming met de conclusie van de advocaat-generaal (hierna: A-G), ${ }^{17}$ het cassatieberoep en deed de zaak af op de voet van artikel 81 lid 1 Wet RO. Kern van het geschil tussen partijen betrof de vraag of bij de vaststelling van hetgeen een erfgenaam/legitimaris krachtens erfrecht verkrijgt, moet worden uitgegaan van de waarde daarvan ten tijde van het overlijden van erflater of ten tijde van de verdeling. De kantonrechter had hieromtrent overwogen:

'Als voor de vaststelling van de legitieme portie, zoals in het testament vastgesteld, dient te worden uitgegaan van de waarde van de goederen ten tijde van het 
overlijden van erflater, dan ligt het in de rede om ter vaststelling van de aanvulling op de legitieme portie - waarbij dus rekening gehouden moet worden met een verkrijging krachtens erfrecht - evenzeer wordt uitgegaan van de waarde ten tijde van overlijden van erflaatster, hetgeen [de Vereffenaar] in zijn berekening ook heeft gedaan en gemotiveerd onderbouwd.'

De kantonrechter heeft met 'aanvulling op de legitieme' kennelijk gedoeld op het bedrag dat als legitimaire vordering resteert nadat de waarde van hetgeen de legitimaris krachtens erfrecht verkrijgt in mindering op zijn legitieme portie is gebracht. Dit in aanmerking genomen, is hetgeen volgens de kantonrechter in de rede ligt mijns inziens juist; het geeft naar mijn mening geldend recht weer. Buiten kijf staat dat de legitieme porties worden berekend over de waarde van de goederen van de nalatenschap op het tijdstip onmiddellijk na het overlijden van erflater. Dit bepaalt artikel 4:65 in samenhang met artikel 4:6 BW. En eveneens is duidelijk, zie artikel 4:71 BW, dat de waarde van al hetgeen een legitimaris krachtens erfrecht verkrijgt in mindering komt van zijn legitieme portie. Krachtens erfrecht verkrijgt de erfgenaam/legitimaris een erfdeel. Dat erfdeel verkrijgt hij door de aanvaarding, die volgens artikel 4:190 lid 4 BW terugwerkt tot het ogenblik van het openvallen van de nalatenschap. ${ }^{18}$ In het berechte geval was de gerealiseerde netto-opbrengst van de woning lager dan de (WOZ-)waarde ten tijde van het overlijden.

140 De A-G komt tot een tegengesteld oordeel. Zij legt er in 3.10-3.24 van haar conclusie grote nadruk op dat het bij de toerekening gaat om wat de legitimaris 'daadwerkelijk als erfgenaam verkrijgt, derhalve om het bedrag dat de legitimaris bij de verdeling als erfdeel uit de nalatenschap [ontvangt]', waarbij zij ook nog vermeldt dat uit jurisprudentie en wetsgeschiedenis bovendien geen aanknopingspunten voor een andere uitleg van artikel 4:71 BW volgen. De A-G is van oordeel dat onderdeel 1 van het cassatiemiddel slaagt, mits artikel 80 lid 1 Wet $\mathrm{RO}$ in dit cassatieberoep niet aan de behandeling van de rechtsklacht in de weg staat, zoals zij blijkens haar conclusie tot verwerping van het cassatieberoep van oordeel is.

De Hoge Raad doet de zaak af op de voet van artikel 81 lid 1 Wet RO met de gebruikelijke motivering dat het niet nodig is om antwoord te geven op vragen die niet van belang zijn voor de eenheid of de ontwikkeling van het recht. Een antwoord op de vraag per welk tijdstip de waarde van hetgeen een legitimaris krachtens erfrecht verkrijgt, dient te worden vastgesteld, lijkt mij wel van belang voor de ontwikkeling van het recht. Ik neem aan dat de Hoge Raad, in aanmerking genomen artikel 80 lid 1 Wet RO, geen ruimte heeft gezien om een oordeel te

18. Ik wijs hier ook op art. 4:66 BW. Daaruit volgt dat de waarde van een toe te rekenen gift dezelfde is die de omvang van de legitimaire massa heeft bepaald. Zie Asser/Perrick 4 2017/320. Dus ook indien de legitimaris nog gerechtigd is tot een geschonken goed en dat goed sinds de schenking (aanzienlijk) in waarde is gedaald. geven over de rechtsklacht tegen de bestreden beschikking van de kantonrechter.

Het oordeel van de A-G is naar mijn mening onjuist. Wat de legitimaris krachtens erfrecht verkrijgt, is zijn erfdeel en dat dient te worden gewaardeerd per het tijdstip waarop hij het erfdeel verkrijgt. Zou het oordeel van de A-G juist zijn, dan zou dit principieel onjuist zijn. De hoogte van de legitimaire vordering zou worden bepaald met inachtneming van de waarde van de goederen van de nalatenschap onmiddellijk na het overlijden van de erflater en bij de toerekening wordt een lagere waarde toegepast. Dit zou naar mijn mening alleen aanvaardbaar zijn indien ook de legitimaire vordering met inachtneming van de lagere waarde zou worden herberekend. Maar daaraan staat artikel 4:65 in verbinding met artikel 4:6 BW in de weg. Voorts zou de door de A-G aangehangen opvatting tot allerlei praktische problemen en willekeurige resultaten kunnen leiden. Allereerst zou de moeilijkheid ontstaan dat de vereffenaar de uitdelingslijst eerst kan opmaken nadat de nalatenschap is verdeeld en is komen vast te staan wat de waarde per het tijdstip van verdeling is van hetgeen de erfgenaam door de verdeling verkrijgt. Want in die benadering van de A-G kan de resterende legitimaire vordering eerst na de verdeling worden vastgesteld. Dit terwijl het uitgangspunt van de wet nu juist is dat vereffening aan verdeling voorafgaat. Zie onder meer artikel 4:203 lid 1 onder b en 4:204 lid 1 onder b BW, op grond waarvan de rechtbank een vereffenaar kan benoemen 'wanneer tot een verdeling van de nalatenschap wordt overgegaan voordat deze vereffend is', onderscheidenlijk 'wanneer tot een verdeling van de nalatenschap wordt overgegaan voordat de opeisbare schulden daarvan zijn voldaan'. En uit artikel 4:211 lid 2 tweede zin BW volgt dat de erfgenamen niet zonder medewerking van de vereffenaar of machtiging van de kantonrechter tot verdeling van de goederen van de nalatenschap kunnen overgaan. In het berechte geval was de woning voorafgaande aan de verdeling verkocht en waren voor de te verdelen woning contanten in de plaats gekomen. De omvang van de verkoopprijs, en daarmee de contanten, staat daarmee vast voorafgaande aan het tijdstip dat de vereffenaar de uitdelingslijst opmaakt. Dat maakt de zaak echter niet principieel anders.

Ik noem nog een andere bepaald niet theoretische situatie. Tot de nalatenschap behoort een omvangrijke effectenportefeuille. Er zijn voldoende liquide middelen om de schulden van de nalatenschap, in het bijzonder de erfbelasting, te voldoen. De vereffenaar is daarom niet verplicht een gedeelte van de effecten zo spoedig mogelijk na zijn infunctietreding te gelde te maken om de schulden van de nalatenschap te voldoen. ${ }^{19} \mathrm{Op}$ het tijdstip van de verdeling is de waarde van de effectenportefeuille aanzienlijk gedaald ten opzichte van het tijdstip van overlijden van erflater. De erfgenamen ver-

19. Zie over deze verplichting van de vereffenaar Asser/Perrick 4 2017/621a en voor de overeenkomstige verplichting van de executeur Asser/Perrick 4 2017/696. 
delen de goederen van de nalatenschap. De wijze van verdeling mag geen invloed hebben op de resterende legitimaire vordering. Gaat de erfgenaam/legitimaris akkoord met een vordering in contanten wegens onderbedeling, dan neemt hij als het ware zijn verlies. Niet de waarde van deze vordering, maar de waarde van zijn erfdeel op het tijdstip van overlijden van de erflater bepaalt de omvang van zijn resterende legitimaire vordering. Worden aan de erfgenaam/legitimaris effecten toebedeeld, dan is de waarde van deze effecten op het tijdstip van verdeling evenmin van invloed op de omvang van zijn resterende legitimaire vordering. In het laatste geval behoudt hij wel de kans dat hij profiteert van een stijging van de waarde van de aan hem toebedeelde effecten.

Een aan een legitimaris gemaakt legaat verkrijgt deze eveneens krachtens erfrecht. Ook de waarde daarvan komt in mindering van zijn legitieme portie. En ook in dat geval is de waarde van het legaat ten tijde van het overlijden van erflater beslissend. Het legaat wordt verkregen met het overlijden zonder dat aanvaarding nodig is. ${ }^{20}$ Het feit dat het legaat in waarde is gedaald, of gestegen, op het tijdstip van afgifte van het legaat heeft geen invloed op het bedrag dat volgens artikel 4:71 BW in mindering komt van de legitieme portie.

\section{Conclusies}

De belangrijkste conclusies uit het vorenstaande zijn:

a. De door artikel 4:218 lid 3 en 5 BW in verbinding met artikel $187 \mathrm{Fw}$ gegeven procedurele regels voor het verzet tegen de rekening en verantwoording en de uitdelingslijst zijn slechts van toepassing indien de vereffenaar deze heeft neergelegd overeenkomstig artikel 4:218 lid $1 \mathrm{BW}$.

b. Gaat het om een beschikking van de kantonrechter op verzet, dan betekent het feit dat tegen die beschikking slechts beroep in cassatie kan worden ingesteld, dat artikel 80 lid 1 Wet RO van toepassing is, met als gevolg dat in cassatie slechts een beperkte rechterlijke toetsing mogelijk is. Deze beperking geldt niet indien er een rechter-commissaris is benoemd en de beschikking op het verzet door de rechtbank wordt gegeven.

c. Een schuldeiser dient zich in het bijzonder in verband met de onder $\mathrm{b}$ vermelde conclusie te realiseren dat hij zijn vorderingsrecht en/of de voorrang die zijn vordering toekomt op de voet van artikel 4:223 lid 2 eerste zin BW kan doen vaststellen door de rechter.

d. Indien de rekening en verantwoording niet behoeft te worden neergelegd, geschiedt zij an hen die recht op het overschot hebben. Het bepaalde aangaande de voogdijrekening vindt overeenkomstige toepassing. Tegen een beschikking van de kantonrechter waardoor hij een geschil beslist dat bij de rekening is gerezen, staan volgens de algemene regels van het $\mathrm{Rv}$ hoger beroep en beroep in cassatie open.

e. Ik heb verdedigd dat in het onder a bedoelde geval ook degenen die recht op het overschot hebben, bezwaar kunnen maken tegen de rekening en verantwoording indien de vereffenaar naar hun oordeel een schuldeiser ten onrechte heeft voldaan voor een naar hun oordeel te hoog bedrag.

f. Bij de berekening van de resterende legitimaire vordering van de erfgenaam/legitimaris dient de waarde van hetgeen hij krachtens erfrecht verkriigt en die volgens artikel 4:71 BW in mindering op zijn legitieme komt, te worden bepaald per het tijdstip van het overlijden van erflater. De waarde van zijn erfdeel per dat tijdstip is beslissend. 